\title{
The Influences of Promising Feedstock Variability on Advanced Biofuel Production: A Review
}

Cherng-Yuan Lin

National Taiwan Ocean University, Taiwan, Lin7108@ntou.edu.tw

Follow this and additional works at: https://jmstt.ntou.edu.tw/journal

Part of the Fresh Water Studies Commons, Marine Biology Commons, Ocean Engineering Commons, Oceanography Commons, and the Other Oceanography and Atmospheric Sciences and Meteorology Commons

\section{Recommended Citation}

Lin, Cherng-Yuan (2022) "The Influences of Promising Feedstock Variability on Advanced Biofuel Production: A Review," Journal of Marine Science and Technology. Vol. 29: Iss. 6, Article 1.

DOI: $10.51400 / 2709-6998.2552$

Available at: https://jmstt.ntou.edu.tw/journal/vol29/iss6/1

This Review is brought to you for free and open access by Journal of Marine Science and Technology. It has been accepted for inclusion in Journal of Marine Science and Technology by an authorized editor of Journal of Marine Science and Technology. 


\title{
REVIEW
}

\section{The Influences of Promising Feedstock Variability on Advanced Biofuel Production: A Review}

\author{
Cherng-Yuan Lin*
}

Department of Marine Engineering, National Taiwan Ocean University, Keelung 20224, Taiwan

\begin{abstract}
The contribution of biofuels is expected to continuously increase in the global fuel market, as they are environmentally-friendly and provide renewable energy. Four generations of biofuels are categorized and are primarily based on their feedstock sources and the production technologies that are used. The influence of promising feedstock types and the availability on the production technologies and the fuel properties of advanced-generation biofuels are not systematically examined in the literature. Hence, this research extensively reviews the potential impact of feedstock sources and their variability on the production and characteristics of biofuels. The approaches of theoretical analysis and inference referred to relevant works in the literature were applied. The findings suggest that the potency of the commercialized mass production of advanced-generation biofuels is facilitated by a much more flexible selection and the sufficient availability of promising feedstocks. Lignocellulose biomass is recognized as the most significant feedstock source for second-generation biofuels, while microalgae do the same for third-generation biofuels. Moreover, the microalgae of some strains are able to produce the highest amount of bio-alcohol of all available feedstock sources. The cell walls of lignocellulose biomass and microalgae mostly consist of lignin compounds and cellulose materials, respectively. Biological pretreatment is considered to be the most promising process, prior to biofuel production. The biofuel yields from lignocellulose biomass and microalgae, using biological pretreatments, could increase by $120 \%$ and $22-159 \%$, respectively, in comparison with those of any other pretreatment process. Moreover, more double bonds and larger unsaturated fatty acids in raw lipids cause the inferior oxidative stability, but superior fluidity of biofuel. The possible impact of Genetically-Modified Crops (GMC) on the eco-environment and human genes remains a serious concern and requires further tracking and analysis. Genetically-modified technology is still immature to achieve the expected characteristics of biofuels from those modified crops. The unceasing exploitation of promising biomass feedstock sources is crucial for the rapid and steady development of advanced-generation biofuels.
\end{abstract}

Keywords: Lignocellulose material, Biofuel, Feedstock variability, Energy crop, Fuel characteristics

\section{Introduction}

B ioenergy, which accounts for $10 \%$ of the global renewable energy, has become one of the major options for the supply of energy [1-4]. The two most distinguished bioenergy examples are biodiesel and bioethanol. In particular, bioethanol has been used widely as an alternative fuel to petroleum-derived gasoline for on-road vehicles and marine vessels [5-7]. It is primarily made from sugarcane, provides about half of the global bioethanol demand and is regarded as one of the most successful examples of biofuel development [8-12]. The contribution of biofuels to the total global renewable energy is expected to increase continuously [13-15], and thus, the dependence on fossil fuels as an energy source will be reduced accordingly. The USA has been a global leader in biofuel production and consumption, particularly bio-ethanol and biodiesel. The amount of biodiesel production and consumption between 2010 and 2017 [16] in the USA, is shown in units of millions of gallons (Mil. Gal.) in Fig. 1. The

Received 21 April 2020; revised 29 September 2020; accepted 7 July 2021.

Available online 27 December 2021

* Fax: +886 224622307.

E-mail address: Lin7108@ntou.edu.tw. 
biodiesel industry appears to have developed vigorously in the USA and the rest of the world since 2010.

Biofuel belongs to the group of carbon-negative energy, which implies that the total quantity of $\mathrm{CO}_{2}$ captured and consumed is more than the $\mathrm{CO}_{2}$ emissions during the life-cycle of such bioenergy [17-19]. Hence, bioenergy is regarded as an environmentally-friendly energy resource. The global $\mathrm{CO}_{2}$ release can be reduced by replacing more fossil fuels with bioenergy. In the European Union (EU), $20 \%$ of greenhouse gases (GHGs) are emitted from the transportation sector [20-22]. The widespread use of biofuels will thus help to diminish the threat of the greenhouse gas effect and the extent of global climate change.

The global production and usage of first-generation biofuels are steadily growing, with the development of more mature production techniques $[23,24]$. However, the feedstocks used for the firstgeneration biofuels are mostly from agricultural crops, which have been a major source of human food for thousands of years. Crop prices have thus soared with the global development of biofuels. In addition, the eco-environment and habitats of the original creatures have been destroyed by the unrestricted expansion of arable land for the cultivation of crops for biofuels [25-27]. First-generation biofuels are thus considered to be the biofuel option that has the least effect on sustainable development $[28,29]$. The shortcomings of first-generation biofuels have actively facilitated the rapid development of second- and third-generation biofuels, which are also referred to as advanced-generation biofuels in

\begin{tabular}{ll|}
\hline Nomenclature \\
CAPEX & Capital expenditure \\
CSE & Conventional solvent extraction \\
EU & European Union \\
GHG & Greenhouse gas \\
GMC & Genetically modified crop \\
LCB & Lignocellulose biomass \\
MSW & Municipal solid waste \\
OPEX & Operating expenditure \\
PBR & Photobioreactor \\
PSSE & Physical-supported solvent extraction \\
SFE & Supercritical fluid extraction \\
SRC & Short-rotation coppice \\
WRF & White-rot fungi \\
\hline
\end{tabular}

this article. The major difference between firstgeneration and advanced-generation biofuels lies in their feedstock source [30-32]. In contrast to cropderived feedstock for the first generation biofuels, non-foods, particularly lignocellulose-based materials, are generally used for the production of the second-generation biofuels [33-35]. These raw lignocellulose materials include agro-industrial residue or architectural waste, such as wood chips, grass, stalks or the boughs of plants, wheat straws, rice husks, etc. [36,37]. Microbial organisms, such as algae, cyanobacteria, and bacteria are recognized as the major feedstock used for third-generation biofuels $[38,39]$. Biohydrogen and bioelectricity, which are produced from a photosynthetic mechanism, are considered as fourth-generation biofuels; however, this category has not yet been widely recognized. The developing trends of the general feedstocks used and the typical biofuel characteristics of the

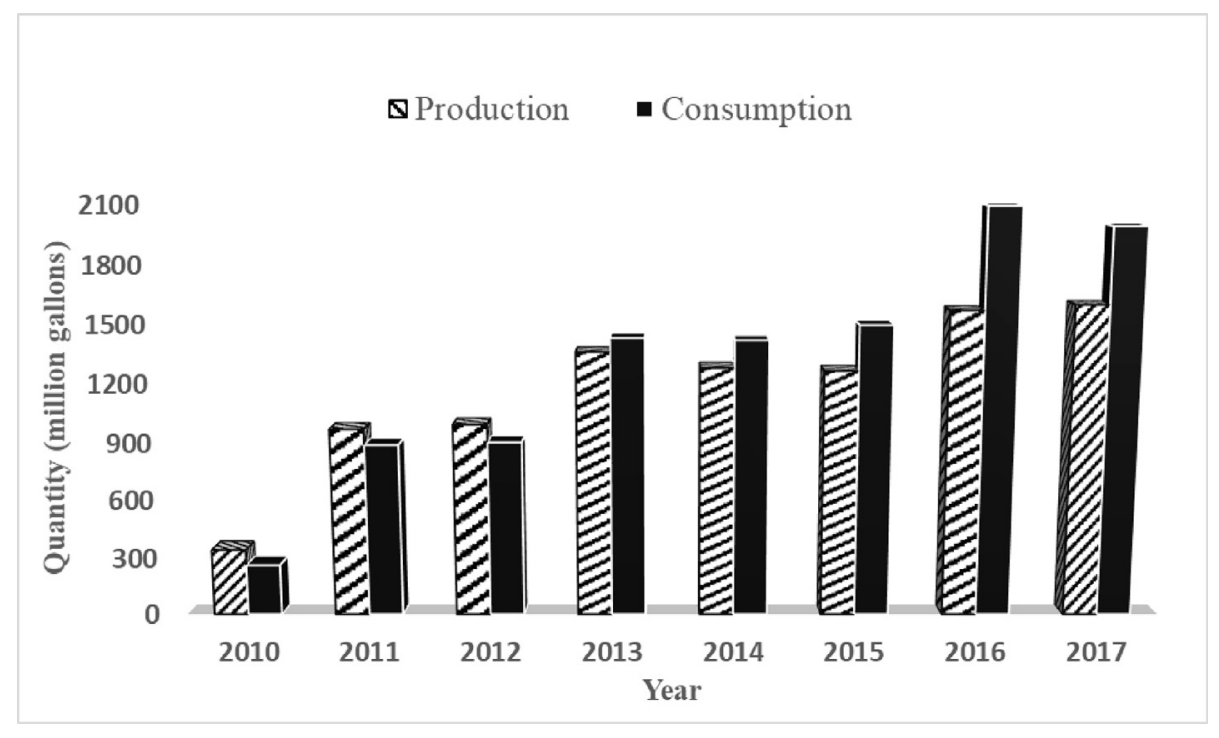

Fig. 1. Production and Consumption of biodiesel between 2010 and 2017 in the USA [16]. 


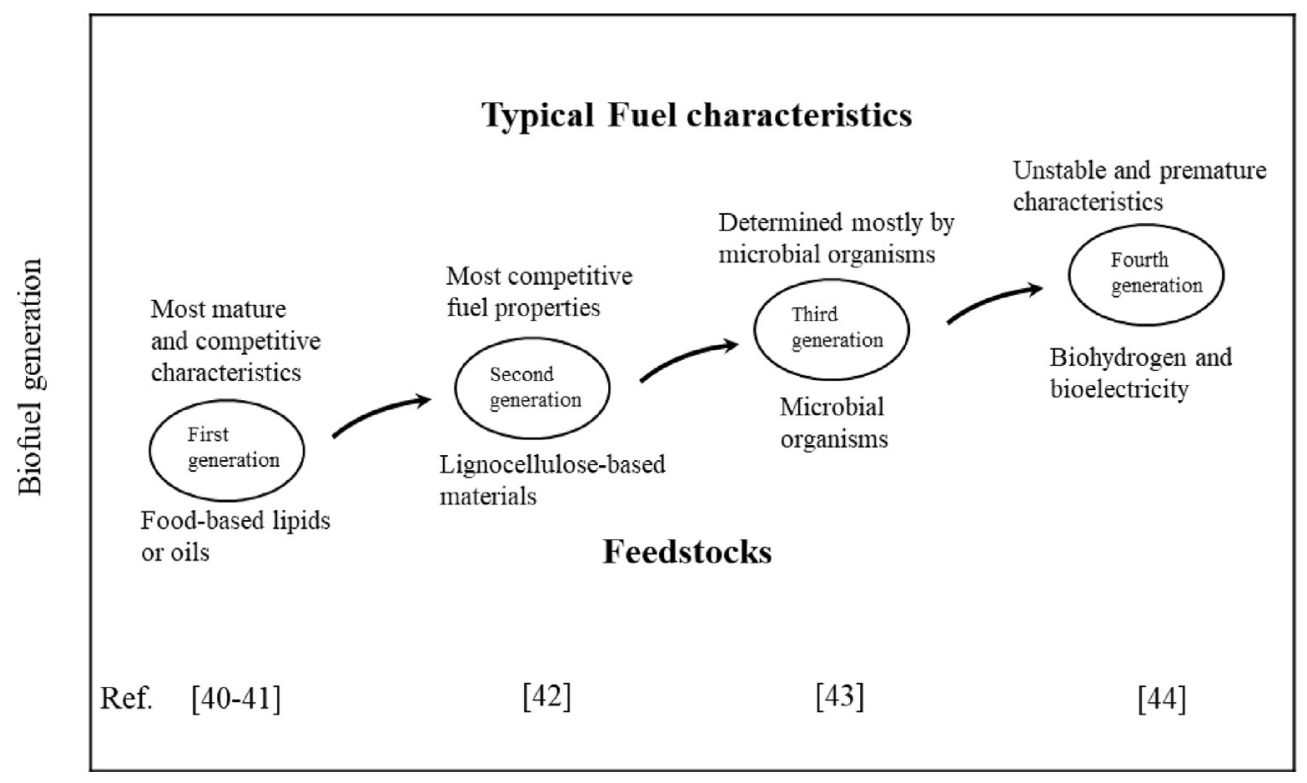

Fig. 2. Feedstock resource and typical fuel characteristics of corresponding generation biofuels.

first-to the fourth-generation biofuels are illustrated in Fig. 2. Non-edible feedstocks, including agroarchitectural waste and lignocellulose materials and microbial organisms, are generally used to produce advanced-generation biofuels. The biofuels of the various generations and their corresponding feedstock sources, fuel characteristics and representative types are shown in Table 1 [40-44]. The more abundant feedstock resources, together with a variety of advanced manufacturing technologies, have facilitated the fast development of advanced-generation biofuels.

The chemical composition, fatty acid profile, characteristics, and availability of the potential feedstocks directly determine the fuel characteristics and the development trends of specific biofuels. However, the influence of promising feedstocks, particularly lignocellulose materials, on biofuel development has not been reviewed in the literature. The major works reviewed in the literature are summarized in Table 2. Dulrue et al. [45] used four evaluation criteria to compare various technologies from cultivation to the oil-upgrading stage. Chen et al. [46] reviewed the economic and technological difficulties in the production of biodiesel from microalgae. Lin and Lu [47] critically reviewed the sustainability criteria, as well as the certification and production technologies of biofuels. Tercero et al. [48] conducted a technical evaluation of the biodiesel that was cultured from microalgae in a closed-pond photobioreactor, while Li et al. [49] reviewed various lipid extraction methods for biofuel production. Lee et al. [50] reviewed the lipid extraction technologies and cell lysis methods from microalgae. Kumari and Singh [51] considered the different pretreatment methods of lignocellulosic waste, while Suparmaniam et al. [52] reviewed the configuration and design of a modern photobioreactor (PBR) for culturing microalgae. However, the various promising feedstocks for the production of various-generation biofuels have not been properly evaluated in the literature as yet. Hence, the recent development of potential feedstock sources and production technologies for advanced biofuels are systematically reviewed in this study. Moreover, the types, chemical profiles, and characteristics of diverse lignocellulose and micro-organism feedstocks are examined. The potential impact of the biomass feedstock variability on the fuel properties of advanced biofuels are finally discussed and reviewed in the manuscript.

\section{Methodology used in this study}

This review work used the approaches of theoretical analysis and the inference referred to previous relevant works published in the literature. The research findings obtained in this study are then summarized. The research experience and results derived from the experiments carried out in the laboratory of the author are also considered, while preparing the manuscript. The primary aim of this study is to construct a relationship between the availability of various feedstock resources, their production technologies, as well as the fuel characteristics of advanced-generation biofuels. 


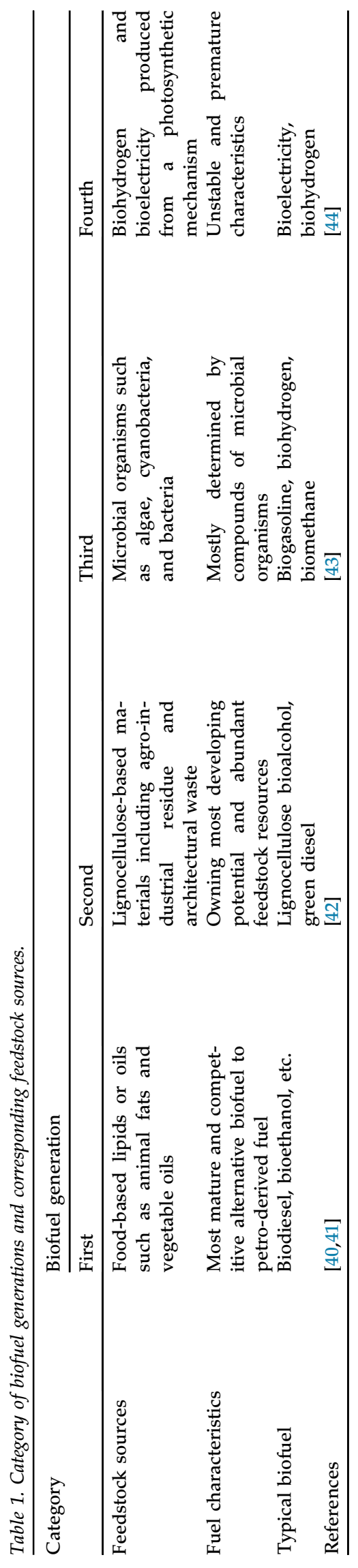

This study originates from the necessity to develop renewable biofuels as an alternative for petroleum-derived diesel or gasoline, to mitigate for their greenhouse gas effects and enhance ecofriendly environment protection, and to search for promising feedstocks, which is considered to be the most crucial step in the promotion of biofuel growth. The literature regarding the available potential feedstocks, including food-based lipids and oils, lignocellulose-based materials, microbial organisms, etc. for biofuel production, are extensively collected and evaluated. The fatty acid profiles of biofuels made from various representative types of feedstock are carefully assessed, by comparing different fatty acids compounds. After a thorough review and evaluation of the promising feedstocks for manufacturing advanced-generation biofuels, this study ends by providing adequate suggestions for promoting biofuel competition.

\section{Lignocellulose-based materials for the production of advanced-generation biofuels}

The major feedstocks used for manufacturing first-generation bio-alcohol are sugar- or starchrich crops, such as sugarcane, beet, corn, wheat, sorghum, etc. Bio-alcohol, particularly bioethanol and biobutanol, can be directly produced through processes of fermentation and distillation, followed by water removal, for those feedstocks that are sugar-rich [53-55]. Enzymatic saccharification is carried out prior to fermentation for converting starch into sugar, when starch-abundant feedstocks are used [56,57]. Much more abundant feedstocks, rather than those that are crop-based, can be used for bio-alcohol production, and these include lignocelluloses, perennial plants, such as miscanthus and switchgrass, wood chip, rice straw, and bagasse [58-60]. These abundant feedstocks can be used to produce second-generation bio-alcohols, as their growth does not compete with fertile land, and they are not edible food sources. In addition, feedstocks that contain rich carbohydrates can also be used to produce bio-alcohol, with the help of adequate microorganisms, for example, enzymes [61,62]. Various types of feedstock, from the conventional sugar- and starchbased types to those that are cellulose-, lignin- and microalgae-based, are all available for bio-alcohol production. The production quantity of bio-alcohol per growing area of microalgae could reach about 5000-15000 gallons/acre, which is 13 times greater than that of switchgrass, 23 times greater than that of sugarcane, and even 46 times greater than that of sweet sorghum [63-65]. 
Table 2. Previous review work of relevant studies.

\begin{tabular}{|c|c|}
\hline References & Major review works \\
\hline Delrue et al., 2012 [45] & $\begin{array}{l}\text { Four evaluation criteria, including greenhouse gases (GHG), the emission rate, the water foot- } \\
\text { print, and the Net Energy Ratio (NER) were used to compare various technologies for each stage } \\
\text { from cultivation to oil upgrading. It was concluded that low-carbon energy sources are necessary } \\
\text { for reducing GHG emissions. }\end{array}$ \\
\hline Chen et al., 2017 [46] & $\begin{array}{l}\text { An economic evaluation of and the technological difficulties in the production of biodiesel from } \\
\text { microalgae are reviewed. The production costs of microalgae biodiesel are mainly from micro- } \\
\text { algae cultivation, followed by the harvesting and lipid extraction. The industrialization of the } \\
\text { biodiesel production process from microalgae is also proposed. }\end{array}$ \\
\hline Lin and $\mathrm{Lu}, 2021$ [47] & $\begin{array}{l}\text { The sustainability criteria, certification and production technologies for biofuel products are } \\
\text { critically reviewed. The perspectives and trends of advanced biofuels are evaluated for their } \\
\text { future development according to a policy and techno-economic analysis. This study suggests the } \\
\text { application of advanced purification and conversion processes to enhance the competitiveness of } \\
\text { advanced biofuels. The government policies for advocating biofuel development are discussed. }\end{array}$ \\
\hline Tercero et al., 2014 [48] & $\begin{array}{l}\text { A production plant for biodiesel from microalgae that have been cultured in a closed pond } \\
\text { photobioreactor (PBR) is technically evaluated. Aspen Plus }{ }^{\circledR} \text { was applied to simulate the whole } \\
\text { production process. Both the operating expenditure (OPEX) and capital expenditure (CAPEX) } \\
\text { were considered in order to carry out an economic analysis. The results showed that the current } \\
\text { technology for the manufacture of biodiesel from microalgae is not economically competitive } \\
\text { with that of petroleum-derived diesel. }\end{array}$ \\
\hline Li et al., 2019 [49] & $\begin{array}{l}\text { The major extraction methods in biofuel production, including Conventional Solvent Extraction } \\
\text { (CSE), Supercritical Fluid Extraction (SFE), Physical-supported Solvent Extraction (PSSE), etc., } \\
\text { are reviewed. Their extraction principles, limitations and application are also discussed in this } \\
\text { study. }\end{array}$ \\
\hline Lee et al., 2021 [50] & $\begin{array}{l}\text { The lipid extraction technologies and cell lysis methods for microalgae are reviewed. Deep } \\
\text { eutectic solvents, switchable solvents, ionic liquids, and organic solvents are considered for } \\
\text { extracting lipids from microalgae. Single-step processes, together with cell disruption, are found } \\
\text { to be more effective for lipid extraction. }\end{array}$ \\
\hline Kumari and Singh, 2018 [51] & $\begin{array}{l}\text { Lignocellulosic waste is considered as a feedstock for biofuel production. A suitable pretreatment } \\
\text { process, such as physical, chemical, biological, as well as a combination of these, would be used } \\
\text { prior to primary production approach. The different pretreatment methods, biomass resources } \\
\text { and chemical compositions are compared and discussed. }\end{array}$ \\
\hline Suparmaniam et al., 2019 [52] & $\begin{array}{l}\text { Microalgae are cultured in a modern photobioreactor (PBR) system, from a tubular to a flat panel. } \\
\text { The PBR configuration and design improvement for the microalgae cultivation system are } \\
\text { reviewed in order to enhance the economic benefits during the cultivation and harvest processes. } \\
\text { This article also attempts to produce microalgae biofuel by using a more cost-effective and } \\
\text { sustainable approach. }\end{array}$ \\
\hline
\end{tabular}

Due to the limited available arable land for growing food-based feedstocks, the quantity of firstgeneration biofuels that are produced is by far not enough to effectively replace fossil fuels [66]. In addition, the production technology of first-generation biofuels must be improved, particularly from the perspective of both the stability of its fuel properties and its mass production rate [67-69]. Therefore, the development of competitive production technology for advanced biofuels has been regarded as a crucial trend for the growth of bioenergy. The feedstocks of second-generation biofuels are primarily provided by non-foods, particularly lignocellulose-based raw materials and Municipal Solid Waste (MSW) [70,71]. In addition, advanced production technology of second- and third-generation biofuels is generally not at a mature stage, and thus their production costs and selling prices are still significantly higher than those of first-generation biofuels [72-74]. Hence, the abundance of feedstock resources and the extent of the maturity of the manufacturing technologies show that there is an adverse trend in the sequential generation of biofuels, and this is shown in Fig. 3 . This means that the feedstock resources of the firstgeneration biofuels, which are produced by the highest mature technology, are the most limited and are primarily sourced from edible oils or animal fats. In contrast, the manufacturing technologies of advanced-generation biofuels are still developing. However, the feedstock resources for producing those biofuels are much more abundant than those used for first-generation biofuels. This implies that much more effort should be made to improve the production processes and reduce the manufacturing expenditure, particularly in the feedstock pretreatment [75-77] of advanced-generation biofuels.

Adequate pretreatment is generally required in the whole production process of advanced secondor third-generation biofuels. For example, hydrolysis is a typical pretreatment method for cellulose bio-alcohol production [78,79]. Either a physical 


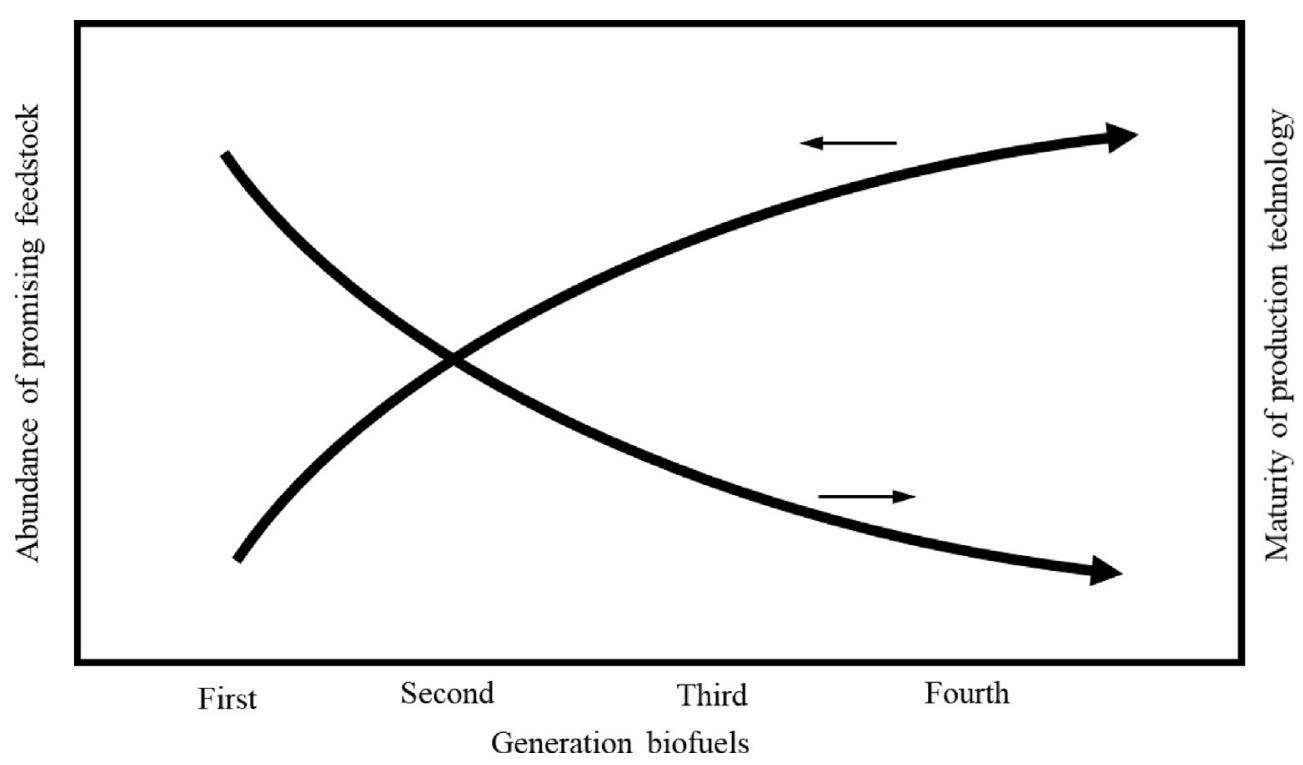

Fig. 3. Developing trends of abundance of promising feedstocks and maturity of production technology for various generation biofuels.

method, using high-temperature steam, a chemical method using acid or alkali hydrolysis catalyst $[80,81]$, or a cellulose digesting enzyme method $[82,83]$, may be adopted in the pretreatment process, based on a comprehensive consideration of the processing cost, the feedstock material used, and the processing time required in the whole lignocellulose-based bio-alcohol production process [84-86].

\section{The biological pretreatment of lignocellulose biomass and microalgae}

The cell wall of lignocellulose biomass is generally composed of $10-35 \%$ lignin, $30-50 \%$ cellulose and $25-30 \%$ hemicellulose. These three components are jointly linked to form a complex structure, namely, a lignocellulosic matrix [87,88]. In addition, microalgae might consist of $2-40 \%$ lipids, $4-57 \%$ carbohydrates and $8-71 \%$ protein. The actual composition of microalgae depends on the species and the cultivation conditions [89]. Biological pretreatment is regarded as a promising approach for pretreating lignocellulose biomass (LCB) prior to the primary manufacturing process for advancedgeneration biofuels [90]. The pretreatment process is a requisite for the biochemical conversion from lignocellulose, microalgae and bacteria feedstock, because of the rigid and complex matrix of those cell walls. Many pretreatment approaches are available, such as mechanical grinding, milling or chipping, gamma or microwave irradiation, immersion in acid or an alkali solution, or steam explosion, etc. [91]. Biological pretreatment has the dominant advantage of using simple operating equipment, having low energy consumption during processing, having safe and green operating procedures, and having low downstream operating costs [92]. Hence, biological pretreatment is recommended for the production of advanced-generation biofuels. The major difficulty of breaking through the cell wall components of lignocellulose biomass (LCB) lies in the cellulose crystallinity, the accessible surface area and the fact that it is mostly a lignin compound [93]. The cell wall structure of microalgae is different from that of lignocellulose biomass (LCB), due to the absence of persistent lignin content. However, the cell wall component of microalgae is composed of cellulose and pectin, which provides a firm structure, so that hydrolytic enzymes are inhibited from accessing the micro-algal biomass.

The downstream biofuel yield of microalgae cells after biological pretreatment is $22-159 \%$ higher than those without prior biological pretreatment [94]. The biofuel yield from lignocellulose biomass (LCB) might

Table 3. Representative types of the feedstocks used for biofuel production.

\begin{tabular}{ll}
\hline Type & Feedstocks \\
\hline I & $\begin{array}{l}\text { Vegetable oils such as cottonseed oil, rapeseed oil, } \\
\text { and corn oil, etc. }\end{array}$ \\
II & $\begin{array}{l}\text { Agro-industrial residues and architectural waste } \\
\text { including bagasse, spent mushroom substrates, } \\
\text { and wood chips, etc. } \\
\text { Plants through genetic modification such as wil- } \\
\text { low, and eucalyptus, etc. } \\
\text { III }\end{array}$ \\
IV & $\begin{array}{l}\text { Energy crops such as Amaranth, poplar, and } \\
\text { Organic waste like waste cooking oil, olive pulp, } \\
\text { and waste paper stock, etc. } \\
\text { V }\end{array}$ \\
VI & $\begin{array}{l}\text { Microalgae like cyanobacteria, red algae, etc. } \\
\text { cellulosiruptor, etc. }\end{array}$ \\
VII &
\end{tabular}


increase by $120 \%$, while the delignification of LCB by White-Rot Fungi (WRF) is increased between $3 \%$ and $72 \%$ [95]. The biological pretreatment approach has been more widely applied to the pretreatment process of biofuels made from LCB, rather than microalgae. However, the application of the biological pretreatment to microalgae biofuels seems much more promising. This is primarily due to the fact that microalgae are generally composed of lipids, proteins and carbohydrates, which are without recalcitrant lignin compounds [96]. The major purpose of the biological pretreatment of biofuels made from microalgae is to prevent cell-wall breakage and the hydrolysis of the macromolecules [97]. In contrast, lignin removal and the enhancement of the digestibility of cellulose material are the primary objectives of biofuel production from LCB [98]. Biogas production, using anaerobic digestion from microalgae, requires the pretreatment of the hydrolysis of macromolecules, instead of the delignification effect of LCB [99].

Fungi are frequently used to carry out biological pretreatment for the removal of lignin content and to break down the lignocellulosic matrix for LCB, while the hydrolysis of macromolecules and the destruction of the cell walls of microalgae are performed by hydrolytic or enzymatic bacterial pretreatments [100]. The time required for biological pretreatment by bacteria, enzymes and consortia is usually much less than that required by fungi and ensiling [101]. The actual time spent on pretreatment is determined by the biomass type, its composition and its chemical structure. However, much more time is used for the pretreatment process of LCB, especially at its delignification stage [102].

\section{Exploiting diverse feedstock sources for advanced biofuels}

\subsection{Categorizing potential feedstock types}

The continuous exploitation of promising and cost-effective feedstock sources is crucial for the steady development of advanced second- and thirdgeneration biofuels. There are a few, but inconsistent, ways of categorizing feedstock types $[103,104]$. The promising feedstocks for the production of biofuels of various generations can be conveniently categorized into seven types, based on their sources: (I) vegetable oils, such as palm kernel oil, soybean oil, corn oil, castor oil, canola oil, cotton-seed oil, rice bran oil, rapeseed oil, and so on; (II) agro-industrial residues and agricultural waste, including spent mushroom substrates, hay, waste trees, stalks, bagasse, corn waste, straw, wood dust, chips, and so on [105]; (III) plants, such as pasture, reed, willow, eucalyptus, etc. through genetic modification [106]; (IV) energy crops, such as Amaranth, poplar, Brassica campestris, sorghum, beetroot, corns, reed, and purple alfalfa [107]; (V) organic waste, such as waste animal fat, pulp, waste paper stock, waste cooking oil, olive pulp, etc. [108]; (VI) microalgae, such as cyanobacteria (blue-green algae), green algae, red algae, etc. [109]; and (VII) bacteria, such as Clostridium acetobutylicum, Caldicellulosiruptor, Pyrococcus, Thermococcus, etc. [110].

As mentioned above, Type I feedstocks are the major source of first-generation biofuels. The Types II to $\mathrm{V}$ feedstocks are primarily used to produce second-generation biofuels. The Type VI and VII feedstocks are classified as those used for the production of third-generation biofuels. Table 3 shows the seven feedstock types that are used for producing biofuels of the various generations.

\subsection{Fatty acid profiles of biodiesel from various feedstocks}

The chemical properties and fuel characteristics of biofuels were determined by the fatty acid composition of the feedstocks used for production [111]. Animal fats are generally composed of a larger weight fraction of saturated fatty acid, which would cause inferior fluidity properties, especially in cold regions or frigid climate, with a superior oxidative or thermal stability [112]. In addition, more double bonds in the chemical structure of fatty acids of biofuels frequently result in an intense reaction of the biofuel with the surrounding oxygen, which causes structural breakage and the deterioration of fuel properties [113]. Sardine oil-biodiesel, which contains more double bonds and much less saturated fatty acids, were found to have a higher iodine value and a lower kinematic viscosity, in comparison with those of biodiesel, which are made from animal fats, such as chicken fat and pork lard [114].

The Type I, V and VI feedstock types in Table 3 have been extensively used to manufacture biodiesel. The fatty acid profiles of biodiesel produced from the representative feedstocks of Types I, V and VI are compared and revealed in Table 4. The microalgae Chaetoceros muelleri, which is a Type VI feedstock, is cultured in deep-sea water and the extracted lipid is used to make biodiesel. The waste cooking oil belonging to Type $\mathrm{V}$ feedstocks in Table 3 has been widely used to produce biodiesel. The other biodiesel that is shown in Table 4 [115-129] was made from Type I feedstocks in Table 3. The feedstocks, other than Types I, V and VI in Table 3, are more apt to produce other biofuels, such as bio- 
Table 4. Comparison of the fatty acid profiles of biodiesels from various feedstocks (wt. \%).

\begin{tabular}{|c|c|c|c|c|c|c|c|c|c|c|c|c|}
\hline \multirow[t]{2}{*}{ Types of fatty acids } & \multirow{2}{*}{$\begin{array}{l}\text { Chemical } \\
\text { structure }\end{array}$} & \multicolumn{11}{|c|}{ Biodiesel from oils or fats } \\
\hline & & $\begin{array}{l}\text { Camellia } \\
\text { oleifera Abel oil }\end{array}$ & $\begin{array}{l}\text { Waste } \\
\text { cooking oil }\end{array}$ & $\begin{array}{l}\text { Marine } \\
\text { fish oil }\end{array}$ & $\begin{array}{l}\text { Salmon } \\
\text { oil }\end{array}$ & $\begin{array}{l}\text { Chaetoceros } \\
\text { muelleri }\end{array}$ & $\begin{array}{l}\text { Canola } \\
\text { oil }\end{array}$ & $\begin{array}{l}\text { Palm } \\
\text { oil }\end{array}$ & $\begin{array}{l}\text { Rapeseed } \\
\text { oil }\end{array}$ & $\begin{array}{l}\text { Soybean } \\
\text { oil }\end{array}$ & $\begin{array}{l}\text { Sunflower } \\
\text { oil }\end{array}$ & $\begin{array}{l}\text { Tallow } \\
\text { fat }\end{array}$ \\
\hline Myristic acid & $\mathrm{C} 14: 0$ & 0.06 & 0.54 & 3.16 & 5.08 & 47.26 & & 1.10 & & 0.10 & 0.10 & 2.60 \\
\hline Myristoleic acid & $\mathrm{C} 14: 1$ & 0.02 & - & - & - & 1.16 & & - & & & & 0.30 \\
\hline Palmitic acid & $\mathrm{C} 16: 0$ & 10.55 & 14.18 & 19.61 & 15.39 & 6.84 & 4.20 & 42.08 & 4.20 & 11.60 & 6.40 & 24.30 \\
\hline Palmitoleic acid & $\mathrm{C} 16: 1$ & 0.36 & 0.74 & 5.16 & 7.55 & 27.59 & 0.30 & 0.15 & 0.10 & 0.20 & 0.10 & 2.60 \\
\hline Heptadecanoic acid & $\mathrm{C} 17: 0$ & - & 0.17 & 1.82 & 0.46 & - & 0.20 & 3.87 & 0.10 & 0.10 & 0.20 & 2.00 \\
\hline Stearic acid & $\mathrm{C} 18: 0$ & 2.43 & 3.77 & 5.24 & 4.00 & 0.15 & 2.00 & 42.95 & 1.60 & 3.90 & 3.60 & 18.20 \\
\hline Oleic acid & $\mathrm{C} 18: 1$ & 69.07 & 47.51 & 20.94 & 20.76 & 3.32 & 60.40 & 7.03 & 59.50 & 23.70 & 21.70 & 42.20 \\
\hline Linoleic acid & $\mathrm{C} 18: 2$ & 8.42 & 24.83 & 2.69 & 3.78 & 0.55 & 21.20 & 0.48 & 21.50 & 53.80 & 66.30 & 4.40 \\
\hline Linolenic acid & $\mathrm{C} 18: 3$ & 0.29 & 4.97 & 0.90 & 0.99 & 0.06 & 9.60 & - & 8.40 & 5.90 & 1.50 & 1.30 \\
\hline Arachidic acid & $\mathrm{C} 20: 0$ & 0.06 & 0.80 & 4.75 & 0.15 & 2.54 & 0.70 & 0.14 & 0.40 & 0.30 & 0.30 & 0.20 \\
\hline Gondoic acid & $\mathrm{C} 20: 1$ & 0.51 & - & - & - & 0.87 & 1.50 & - & 2.10 & 0.30 & 0.20 & 0.60 \\
\hline Eicosadienoic acid & $\mathrm{C} 20: 2$ & 0.12 & 0.17 & 0.81 & 0.30 & 0.62 & 0.10 & - & 0.10 & & & \\
\hline Eicosatetraenoic acid & $\mathrm{C} 20: 4$ & - & 0.38 & 2.54 & 2.08 & - & & - & & & & \\
\hline Eicosapentaenoic acid & $\mathrm{C} 20: 5$ & - & 0.03 & 3.70 & 9.49 & 0.16 & & - & & & & \\
\hline Behenic acid & $\mathrm{C} 22: 0$ & - & 0.10 & 1.55 & 0.09 & 5.80 & 0.30 & - & 0.30 & 0.30 & 0.60 & 0.10 \\
\hline Docosaenoic acid & $\mathrm{C} 22: 1$ & 7.97 & 0.18 & 0.98 & - & 0.98 & 0.50 & - & 0.50 & 0.10 & 0.10 & 0.10 \\
\hline Docostetraenoic acid & $\mathrm{C} 22: 4$ & - & 0.14 & 3.86 & 0.30 & - & & - & & & & \\
\hline Docospentaenoic acid & $\mathrm{C} 22: 5$ & - & 0.05 & 2.44 & 4.94 & 0.12 & & - & & & & \\
\hline Docoshexaenoic acid & $\mathrm{C} 22: 6$ & - & 0.04 & 15.91 & 13.99 & 1.04 & - & - & & & & \\
\hline Behenate & $\mathrm{C} 24: 0$ & 0.08 & - & - & - & - & - & 0.10 & 0.10 & 0.10 & 0.20 & - \\
\hline Nervonate & $\mathrm{C} 24: 1$ & 0.06 & - & - & - & - & - & - & 0.10 & 0.30 & - & - \\
\hline Saturated fatty acids & - & 13.18 & 19.77 & 37.06 & 25.70 & 62.59 & 7.40 & 48.45 & 6.60 & 16.40 & 11.40 & 47.80 \\
\hline Mono-unsaturated fatty acids & - & 78.00 & 48.37 & 26.35 & 33.35 & 33.92 & 62.50 & 43.10 & 62.30 & 24.70 & 22.10 & 46.50 \\
\hline Long carbon-chain fatty acid & $\mathrm{C} 20-\mathrm{C} 22$ & 8.66 & 1.89 & 37.30 & 39.52 & 13.10 & 3.10 & 0.14 & 3.60 & 1.40 & 1.40 & 1.00 \\
\hline References & & [115] & {$[116,117]$} & [118] & [117] & [129] & {$[121,122]$} & {$[119,120]$} & [123] & [124] & {$[126,127]$} & {$[125,128]$} \\
\hline
\end{tabular}


alcohols, bio-gasoline, or bio-natural gas. The biodiesel produced from palm oil, as shown in Table 4, has the largest saturated fatty acids and stearic acid (C18:0) content, which amounts to 48.45 wt. $\%$ and 42.95 wt. $\%$, respectively. The biofuels made from animal fats, such as tallow fat and fish oil, like marine fish oil and salmon oil, appeared to have a significantly larger content of saturated fatty acids than those from vegetable oils, such as corn oil and sunflower oil. The rapeseed oil biofuel was observed to have the lowest saturated fatty acids and much higher mono-unsaturated fatty acids, which reached $6.6 \mathrm{wt}$. $\%$ and $62.5 \mathrm{wt}$. $\%$, respectively. Moreover, the biodiesel from Camellia oleifera Abel oil consists mostly of mono-unsaturated fatty acids (78 wt. \%). The oleic acid (C18:1) of the C. oleifera Abel oil-biodiesel even amounts to 69.07 wt. \% [115]. This biodiesel is thus considered to have an inferior oxidative stability, but superior low-temperature fluidity, and it is adapted to usage conditions in cold weather.

\subsection{Selection of promising feedstocks for competitive biofuel production}

\subsubsection{Potential resource of vegetable oils for biofuel production}

Vegetable oils are extracted from nuts, seeds, and even the leaves of plants. In addition, oilseeds of some bushes also provide a source of vegetable oils. Nowadays, the seeds of Jatropha curas, Pogamia Pinnata, Calophyllum inophyllum, and castor beans have become common biofuel feedstocks. Some species of wild bushes cannot absorb enough nutrients and water because they grow on unfertile hillsides. Hence, such bush species generally contain neither a high amount of seed oil nor do they have a sufficient economic value [130]. Therefore, in order to increase the quality and quantity of oil sources for biofuel production, these oil crops are required to be properly selected, cultivated, proliferated, and even genetically modified.

The disadvantages of seed oil from Jatropha curas and castor beans include the fact that its content is a toxic substance, manual collection is required, and the seed-oil is very expensive [131,132]. These disadvantages may be effectively resolved by the genetic modification of the plants and the design of automatic collection machinery for such plant seeds. The Jatropha curas seed is considered to be a significantly important raw material source for biodiesel production in South-east Asia and India [133], because it is adaptable and can be grown in barren areas, and its growth has almost no negative impact on tropical rain forests [134]. A few international petroleum companies have devoted many efforts into investigating the biological characteristics of Jatropha curas crops and the efficiency of their conversion to biodiesel [135].

\subsubsection{Lignocellulose materials for the production of second-generation biofuels}

In comparison with the feedstocks of advancedgeneration biofuels, the costs of vegetable oil feedstocks are generally higher [136]. The feedstock costs include growing the nutrients, the breeding, the manual collection of oilseeds, seed transportation, oil extraction, the refining process, and process management [137,138]. Although edible plant oil crops present a high quality of oil and the superior stability of the fuel properties, they are not encouraged to be used as raw materials for advanced-generation biofuels [139]. Instead, agricultural and architectural biomass wastes and lignocellulose materials are the primary feedstock sources of second-generation biofuels. The cost of these materials is relatively lower compared to the plant oil sources described above. In addition, the conversion of such waste into bioenergy complies well with both environmental protection and the development of a circular economy. Agricultural waste, such as the stalks, stems, leaves, etc. of barley, rice, wheat, maize, rye, and other grains, are promising feedstocks for second-generation biofuel production [140,141].

Ligneous plants often contain a higher calorific value than herb plants. In particular, trees are much more adaptable to growth on barren land, so as to avoid competition with food crops grown in arable lands. The lignocellulose materials of trees generally have a higher bioenergy conversion efficiency than herb plants, such as soybean, corn, sugar beet, sugarcane, etc. $[142,143]$. Sawdust, wood chips, and wood waste from the timber industry are also suitable feedstocks for the production of second-generation biofuels $[144,145]$. Moreover, the large-scale proper planning of afforestation can provide an important source of feedstock for biofuel production. Afforestation has additional advantages, including the absorption of carbon dioxide and other greenhouse gases, water and soil conservation, the prevention of landslides in forest areas, ecological protection, and the maintenance of a variety of biological species $[146,147]$. 


\subsubsection{Feedstocks from genetically-modified crops (GMCs) and energy crops for the production of advanced-generation biofuels}

Genetically Modified Crop (GMC) technology has been widely applied for increasing crop yields, improving specific crop characteristics, adapting to harsh environments, such as barren or contaminated soil, decreasing pests and diseases, reducing fertilizer and labor management, resisting climates that are too hot or cold, etc. [148-151]. After being carefully selected, some species of wild crops are also able to be genetically modified for domestication, and they can be adjusted to become more suitable feedstocks of biofuels. However, serious doubt continues as to whether GMC technology will destroy the eco-environmental and human gene factors [152,153]. Moreover, GMC technology is still not mature enough to meet all the targets of modifying crop characteristics, as described above [154,155].

Energy crops can be divided into two types of herbal and Short-Rotation Coppice (SRC). Herbal crops include grass, high famine grass, rye, and other herbaceous species. SRC includes poplar, eucalyptus, willow, bamboo, and other crops, which can be used as paper, building materials, or biofuel feedstock [156-158]. Boehmel et al. [159] found that the highest energy conversion efficiency of energy crops is willow in south-west Germany. Although corn has a higher output energy, it also requires a higher input energy for growing [160]. Miscanthus, which is also an excellent energy crop species, has the dominant advantage of having a high crop yield and low input energy that is required for growth, due to the large amount of fiber contained in its stem structure [161-163]. Suitable herbaceous energy crops include Medicago sativa, alfalfa, Panicum virgatum, reed canary grass, Miscanthus sinensis [164], and so on. Compared to ligneous plants, herbaceous energy crops have the dominant advantage of high management flexibility and a short rotation, and they can easily be changed for the type of crop cultivated [165,166]. Energy crops do not compete with human food and thus have become important feedstock sources for advanced-generation biofuels $[167,168]$.

\subsubsection{The most promising feedstocks from algae and organic waste for the production of advanced- generation biofuels}

Used cooking oil and animal fat, Municipal Solid Waste (MSW), and paper mill waste are categorized as organic waste. The use of organic waste for biofuel production not only reduces the waste quantities and removal costs, but it can also lessen their impact on pollution in the environment [169-171]. Potato peels, which can be recycled to produce bioethanol in the same potato chip factory, are also a representative example of converting organic waste into bioenergy [172].

Algae, including macro- and micro-algae, are the feedstocks with the most potential for manufacturing advanced-generation biofuels, due to their dominant advantage of having a rich lipid content, having a fast proliferation rate, their ability to be cultivated on infertile land and their ability to absorb carbon dioxide $\left(\mathrm{CO}_{2}\right)$ for the photosynthesis of plants [173]. Algae are regarded as the most efficient organisms among all terrestrial plants for converting $\mathrm{CO}_{2}$ to form chlorophyll by means of a photosynthetic reaction [174]. They contain various quantities of triglycerides, lipids, protein and carbohydrates, and the production of diverse biofuels depends on the exact strain of the algae [175]. The five major microalgae groups are green algae, brown algae, red algae, blue-green algae (also termed as Cyanobacteria) and diatoms, which are frequently used to produce advanced-generation biofuels, particularly Cyanobacteria. Genetic engineering technology has been widely used to modify the chemical compounds and fuel properties of algae and to meet the required characteristics of feedstocks for advanced-generation biofuels [176].

The optimum fatty acid profiles, chemical composition and cost-effectiveness of biofuels are considered to be produced from the appropriate mixing of various feedstocks fractions [173]. The cost of biofuels is therefore competitive, due to an adequate compromise between the selling price and fuel properties on the global fuel market.

\section{Conclusions}

Diverse biomass materials, particularly lignocellulose materials, are continuously being exploited for the production of advanced biofuels with superior fuel characteristics. While other review studies only focus on one or two issues of biofuel feedstocks, the potential impact of biomass feedstock variability on the production technology and fuel characteristics of advanced biofuels is systematically reviewed in this article. The potential feedstock resources that are used for the production of advanced generation biofuels for the various fatty acids profiles of biofuels from different raw materials, and for the promising pretreatment procedures of feedstocks, particularly the biological pretreatment method, are also discussed and reviewed in depth in this study. This article will provide helpful information for researchers and industrial professionals 
in the relevant biofuel fields. The major conclusions of this study are summarized below:

(1) Advanced biofuels have much less of a negative impact on the ecological environment than fossil fuels. The contribution from advanced-generation biofuels in the global renewable energy market is expected to increase continuously.

(2) The discrimination of various generations of biofuels is primarily based on the feedstock types that are used for biofuel production. A wider and more flexible selection, at much greater quantities, of promising feedstocks could facilitate the mass production and commercialization of advanced-generation biofuels.

(3) A wide variety of feedstocks is available for the production of advanced-generation biofuels. The potential feedstocks can be classified simply into seven types, based on their sources. Among these, lignocellulose biomass, such as agro-industrial residue and architectural waste, is the most important type of feedstock for the production of second-generation biofuels, while microalgae and bacteria are used for third-generation biofuels.

(4) Bio-alcohol, ranging from conventional sugarand starch-based materials, to cellulose- and lignin-based materials, to various strains of microalgae, can be produced from biomass feedstocks. Some species of microalgae are able to produce bio-alcohol at about 5000-15000 gallons/acre, or 13-46 times that of switchgrass or sweet sorghum.

(5) Vegetable oils that are acquired from seeds, beans, nuts, the leaves of plants, and even the oilseeds of some bushes, are the major raw biomass materials, particularly for first-generation biofuels. Some indigenous oil crops of wild bushes may need to be modified adequately, in order to increase the amount and quality of their seed oils for advanced biofuel production. Energy crops have become a significant biomass source for advanced-generation biofuels, primarily due to the fact they do not compete with human food, as well as their high management flexibility, and their short rotation.

(6) The complex cell wall component of lignocellulose biomass is composed mostly of lignin compounds and is obviously different from the cellulose and pectin walls of microalgae. Biological pretreatment is considered to be most promising for advanced-generation biofuels, due to its dominant advantage of being a green procedure and having low downstream operating costs. The biofuel yield from microalgae cells and lignocellulose biomass increased by $22-159 \%$ and $120 \%$, respectively, after biological pretreatment, in comparison with those without any pretreatment.

(7) The fatty acid profiles of feedstocks primarily determine the fuel characteristics and chemical composition of the biofuels produced. More double bonds and higher unsaturated fatty acids frequently cause property deterioration. The biofuels produced from animal fats and fish oil generally have a higher oxidative stability, but they have inferior low-temperature fluidity.

(8) The unceasing exploitation of promising biomass feedstock sources is a crucial issue for fast and steady development of advanced biofuels. Genetically-modified technology is still immature to achieve the expected characteristics of biofuels from those modified crops. Furthermore, the possible impact of genetically-modified crops on the eco-environment and human genes requires further evaluation and tracking.

\section{Declaration of competing interest}

The author declares no conflict of interest.

\section{Acknowledgements}

The financial support from Ministry of Science and Technology, Taiwan, ROC under Contract No: MOST 107-2221-E-019-056-MY2 and MOST 1092221-E-019-024 is acknowledged.

\section{References}

[1] Popp J, Lakner Z, Harangi-Rakos M, Fari M. The effect of bioenergy expansion: food, energy, and environment. Renew Sustain Energy Rev 2014;32:559-78. https://doi.org/ 10.1016/j.rser.2014.01.056.

[2] Kumar A, Kumar N, Baredar P, Shukla A. A review on biomass energy resources, potential, conversion and policy in India. Renew Sustain Energy Rev 2015;45:530-9. https:// doi.org/10.1016/j.rser.2015.02.007.

[3] Jiang D, Zhuang D, Fu J, Huang Y, Wen K. Bioenergy potential from crop residues in China: availability and distribution. Renew Sustain Energy Rev 2012;16(3):1377-82. https://doi.org/10.1016/j.rser.2011.12.012.

[4] Welfle A. Balancing growing global bioenergy resource demands-Brazil's biomass potential and the availability of resource for trade. Biomass Bioenergy 2017;105:83-95. https://doi.org/10.1016/j.biombioe.2017.06.011Get.

[5] Banerjee S, Kaushik S, Tomar RS. Global scenario of biofuel production: past, present and future. In: Prospects of renewable bioprocessing in future energy systems. Cham: Springer; 2019. p. 499-518. https://doi.org/10.1007/978-3030-14463-0_18.

[6] Suarez-Bertoa R, Zardini AA, Keuken H, Astorga C. Impact of ethanol containing gasoline blends on emissions from a flex-fuel vehicle tested over the Worldwide Harmonized Light duty Test Cycle (WLTC). Fuel 2015;143:173-82. https://doi.org/10.1016/j.fuel.2014.10.076. 
[7] Davis GW. Addressing concerns related to the use of ethanol-blended fuels in marine vehicles. J Sustain Dev Energy, Water Environ Syst 2017;5(4):546-59. https:// doi.org/10.13044/j.sdewes.d5.0175.

[8] Jaiswal D, De Souza AP, Larsen S, LeBauer DS, Miguez FE, Sparovek G, et al. Brazilian sugarcane ethanol as an expandable green alternative to crude oil use. Nat Clim Change 2017;7(11):788. https://doi.org/10.1038/ nclimate3410.

[9] Sant'Anna AC, Shanoyan A, Bergtold JS, Caldas MM, Granco G. Ethanol and sugarcane expansion in Brazil: what is fueling the ethanol industry? Int Food Agribus Manag Rev 2016;19(4):163-82. https://doi.org/10.22004/ ag.econ. 264202.

[10] Moreira JR, Romeiro V, Fuss S, Kraxner F, Pacca SA. BECCS potential in Brazil: achieving negative emissions in ethanol and electricity production based on sugar cane bagasse and other residues. Appl Energy 2016;179:55-63. https:// doi.org/10.1016/j.apenergy.2016.06.044.

[11] Baig KS, Wu J, Turcotte G. Future prospects of delignification pretreatments for the lignocellulosic materials to produce second generation bioethanol. Int J Energy Res 2019; 43(4):1411-27. https://doi.org/10.1002/er.4292.

[12] Welfle A. Balancing growing global bioenergy resource demands- Brazil's biomass potential and the availability of resource for trade. Biomass Bioenergy 2017;105:83-95. https://doi.org/10.1016/j.biombioe.2017.06.011.

[13] Gaurav N, Sivasankari S, Kiran GS, Ninawe A, Selvin J. Utilization of bioresources for sustainable biofuels: a review. Renew Sustain Energy Rev 2017;73:205-14. https:// doi.org/10.1016/j.rser.2017.01.070.

[14] Simionescu M, Albu LL, Raileanu Szeles M, Bilan Y. The impact of biofuels utilisation in transport on the sustainable development in the European Union. Technol Econ Dev Econ 2017;23(4):667-86. https://doi.org/10.3846/ 20294913.2017.1323318.

[15] Mofijur M, Masjuki HH, Kalam MA, Rahman SA, Mahmudul HM. Energy scenario and biofuel policies and targets in ASEAN countries. Renew Sustain Energy Rev 2015;46:51-61. https://doi.org/10.1016/j.rser.2015.02.020.

[16] Javed SA, Zhu B, Liu S. Forecast of biofuel production and consumption in top $\mathrm{CO}_{2}$ emitting countries using a novel grey model. J Clean Prod 2020;276:123997. https://doi.org/ 10.1016/j.jclepro.2020.123997.

[17] Laude A. Bioenergy with carbon capture and storage: are short-term issues set aside? Mitigation and Adaptation Strategies for Global Change. 2019. p. 1-19. https://doi.org/ 10.1007/s11027-019-09856-7.

[18] Muratori M, Kheshgi H, Mignone B, Clarke L, McJeon H, Edmonds J. Carbon capture and storage across fuels and sectors in energy system transformation pathways. Int J Greenhouse Gas Contr 2017;57:34-41. https://doi.org/ 10.1016/j.ijggc.2016.11.026.

[19] Rafiq MK, Bachmann RT, Rafiq MT, Shang Z, Joseph S, Long R. Influence of pyrolysis temperature on physicochemical properties of corn stover (Zea mays L.) biochar and feasibility for carbon capture and energy balance. PLoS One 2016;11(6):e0156894. https://doi.org/10.1371/ journal.pone.0156894.

[20] La Notte A, Tonin S, Lucaroni G. Assessing direct and indirect emissions of greenhouse gases in road transportation, taking into account the role of uncertainty in the emissions inventory. Environ Impact Assess Rev 2018;69: 82-93. https://doi.org/10.1016/j.eiar.2017.11.008.

[21] Dosumu A, Colbeck I, Bragg R. Greenhouse gas emissions as a result of spectators travelling to football in England. Sci Rep 2017;7(1):6986. https://doi.org/10.1038/s41598-01706141-y.

[22] Van Fan Y, Perry S, Klemeš JJ, Lee CT. A review on air emissions assessment: Transportation. J Clean Prod 2018; 194:673-84. https://doi.org/10.1016/j.jclepro.2018.05.151.

[23] Sirajunnisa AR, Surendhiran D, Baskar T, Vijay M, Vijayagopal V, Thiruvengadam S. Current and future perspectives on lipid-based biofuels. In: Prospects of renewable bioprocessing in future energy systems. Cham: Springer; 2019. p. 387-429. https://doi.org/10.1007/978-3030-14463-0_15.

[24] Rulli MC, Bellomi D, Cazzoli A, De Carolis G, D'Odorico P. The water-land-food nexus of first-generation biofuels. Sci Rep 2016;6:22521. https://doi.org/10.1038/srep22521.

[25] Khan S, Siddique R, Sajjad W, Nabi G, Hayat KM, Duan P, et al. Biodiesel production from algae to overcome the energy crisis. HAYATI J Biosci 2017;24(4):163-7. https:// doi.org/10.1016/j.hjb.2017.10.003.

[26] Chen LJ. On urban ecological Construction and protection. Urban Transp Constr 2017;3(2):1-7.

[27] Correa DF, Beyer HL, Fargione JE, Hill JD, Possingham HP, Thomas-Hall SR, et al. Towards the implementation of sustainable biofuel production systems. Renew Sustain Energy Rev 2019;107:250-63. https://doi.org/10.1016/ j.rser.2019.03.005.

[28] Ponte S, Daugbjerg C. Biofuel sustainability and the formation of transnational hybrid governance. Environ Polit 2015;24(1):96-114. 09644016.2014.954776

[29] Ekener E, Hansson J, Larsson A, Peck P. Developing Life Cycle Sustainability Assessment methodology by applying values-based sustainability weighting-Tested on biomass based and fossil transportation fuels. J Clean Prod 2018;181: 337-51. https://doi.org/10.1016/j.jclepro.2018.01.211.

[30] Jambo SA, Abdulla R, Azhar SHM, Marbawi H, Gansau JA, Ravindra P. A review on third generation bioethanol feedstock. Renew Sustain Energy Rev 2016;65:756-69. https:// doi.org/10.1016/j.rser.2016.07.064.

[31] Cuellar-Bermudez SP, Garcia-Perez JS, Rittmann BE, ParraSaldivar R. Photosynthetic bioenergy utilizing $\mathrm{CO}_{2}$ : an approach on flue gases utilization for third generation biofuels. J Clean Prod 2015;98:53-65. https://doi.org/ 10.1016/j.jclepro.2014.03.034.

[32] Behera S, Singh R, Arora R, Sharma NK, Shukla M, Kumar S. Scope of algae as third generation biofuels. Front Bioeng Biotechnol 2015;2:90. https://doi.org/10.3389/ fbioe.2014.00090.

[33] Hassan SS, Williams GA, Jaiswal AK. Moving towards the second generation of lignocellulosic biorefineries in the EU: drivers, challenges, and opportunities. Renew Sustain Energy Rev 2019;101:590-9. https://doi.org/10.1016/ j.rser.2018.11.041.

[34] Wang Y, Ho SH, Ye HW, Nagarajan D, Ren NQ, Li S, ..., Chang JS. Current advances on fermentative biobutanol production using third generation feedstock. Biotechnol Adv 2017;35(8):1049-59. https://doi.org/10.1016/ j.biotechadv.2017.06.001.

[35] Jin M, Slininger PI, Dien BS, Waghmode $S$, Moser BR, Orjuela A, ..., Balan V. Microbial lipid-based lignocellulosic biorefinery: feasibility and challenges. Trends Biotechnol 2015;33(1):43-54. j.tibtech.2014.11.005.

[36] Abraham A, Mathew AK, Sindhu R, Pandey A, Binod P. Potential of rice straw for bio-refining: an overview. Bioresour Technol 2016;215:29-36. https://doi.org/10.1016/ j.biortech.2016.04.011.

[37] Hossain N, Zaini JH, Mahlia TMI. A review of bioethanol production from plant-based waste biomass by yeast fermentation. Int J Technol 2017;8(1):5-18. http://hdl. handle.net/10453/127073.

[38] Neto JM, Komesu A, da Silva Martins LH, Gonçalves VO, de Oliveira JAR, Rai M. Third generation biofuels: an overview. Sustain Bioenergy 2019:283-98. https://doi.org/ 10.1016/B978-0-12-817654-2.00010-1. Elsevier.

[39] Gajda I, Greenman J, Melhuish C, Ieropoulos I. Self-sustainable electricity production from algae grown in a microbial fuel cell system. Biomass Bioenergy 2015;82:87-93. https://doi.org/10.1016/j.biombioe.2015.05.017.

[40] Lanjekar RD, Deshmukh D. A review of the effect of the composition of biodiesel on NOx emission, oxidative 
stability and cold flow properties. Renew Sustain Energy Rev 2016;54:1401-11. https://doi.org/10.1016/ j.rser.2015.10.034.

[41] Bertrand E, Vandenberghe LP, Soccol CR, Sigoillot JC, Faulds C. First generation bioethanol. In: Green fuels technology; 2016. p. 175-212. https://doi.org/10.1007/978-3319-30205-8_8.

[42] Nguyen QA, Yang J, Bae HJ. Bioethanol production from individual and mixed agricultural biomass residues. Ind Crop Prod 2017;95:718-25. https://doi.org/10.1016/ j.indcrop.2016.11.040.

[43] Suganya T, Varman M, Masjuki HH, Renganathan S. Macroalgae and microalgae as a potential source for commercial applications along with biofuels production: a biorefinery approach. Renew Sustain Energy Rev 2016;55: 909-41. https://doi.org/10.1016/j.rser.2015.11.026.

[44] Raud M, Kilas T, Sippula O, Shurpal NJ. Potentials and challenges in lignocellulosic biofuel production technology. Renew Sustain Energy Rev 2019;111:44-56. https://doi.org/ 10.1016/j.rser.2019.05.020.

[45] Delrue F, Setier PA, Sahut C, Cournac L, Roubaud A, Peltier G, et al. An economic, sustainability, and energetic model of biodiesel production from microalgae. Bioresour Technol 2012;111:191-200. https://doi.org/10.1016/ j.biortech.2012.02.020.

[46] Chen J, Li Q, Chang C, Bai J, Liu L, Fang S, et al. Technoeconomic analysis of biodiesel production from microalgae: a review. Trends Renew Energy 2017;3(2):141-52. https:// doi.org/10.17737/tre.2017.3.2.0035.

[47] Lin CY, Lu C. Development perspectives of promising lignocellulose feedstocks for production of advanced generation biofuels: a review. Renew Sustain Energy Rev 2021; 136:110445. https://doi.org/10.1016/j.rser.2020.110445.

[48] Tercero EAR, Domenicali G, Bertucco A. Autotrophic production of biodiesel from microalgae: an updated process and economic analysis. Energy 2014;76:807-15. https:// doi.org/10.1016/j.energy.2014.08.077.

[49] Li P, Sakuragi K, Makino H. Extraction techniques in sustainable biofuel production: a concise review. Fuel Process Technol 2019;193:295-303. https://doi.org/10.1016/ j.fuproc.2019.05.009Get rights and content.

[50] Lee SY, Khoiroh I, Vo DVN, Kumar PS, Show PL. Techniques of lipid extraction from microalgae for biofuel production: a review. Environ Chem Lett 2020:1-21. https:// doi.org/10.1007/s10311-020-01088-5.

[51] Kumari D, Singh R. Pretreatment of lignocellulosic wastes for biofuel production: a critical review. Renew Sustain Energy Rev 2018;90:877-91. https://doi.org/10.1016/ j.rser.2018.03.111.

[52] Suparmaniam U, Lam MK, Uemura Y, Lim JW, Lee KT, Shuit SH. Insights into the microalgae cultivation technology and harvesting process for biofuel production: a review. Renew Sustain Energy Rev 2019;115:109361. https://doi.org/ 10.1016/j.rser.2019.109361.

[53] Shah YR, Sen DJ. Bioalcohol as green energy e a review. Int J Curr Sci Res 2011;1:57e62.

[54] Mohanty SK, Swain MR. Bioethanol production from corn and wheat: food, fuel, and future. In: Bioethanol production from food crops. Academic Press; 2019. p. 45-59. https:// doi.org/10.1016/B978-0-12-813766-6.00003-5.

[55] Ray RC, Uppuluri KB, Trilokesh C, Lareo C. Sweet sorghum for bioethanol production: scope, technology, and economics. In: Bioethanol production from food crops. Academic Press; 2019. p. 81-100. https://doi.org/10.1016/B9780-12-813766-6.00005-9.

[56] Zabed H, Faruq G, Boyce AN, Sahu JN, Ganesan P. Evaluation of high sugar containing corn genotypes as viable feedstocks for decreasing enzyme consumption during drygrind ethanol production. J Taiwan Inst Chem Eng 2016;58: 467-75. https://doi.org/10.1016/B978-0-12-813766-6.00005-9.

[57] Moshi AP, Hosea KM, Elisante E, Mamo G, Önnby L, Nges IA. Production of raw starch-degrading enzyme by Aspergillus sp. and its use in conversion of inedible wild cassava flour to bioethanol. J Biosci Bioeng 2016;121(4): 457-63. https://doi.org/10.1016/j.jbiosc.2015.09.001.

[58] Roni MS, Cafferty KG, Hess JR, Jacobson JJ, Kenney KL, Searcy E, et al. Lignocellulosic crop supply chains (eg, Miscanthus, switchgrass, reed canary grass, rye, giant reed, etc.). In: Biomass supply chains for bioenergy and biorefining. Woodhead Publishing; 2016. p. 271-91. https:// doi.org/10.1016/B978-1-78242-366-9.00012-5.

[59] Zhang Y, Oates LG, Serate J, Xie D, Pohlmann E, Bukhman YV, ..., Sanford GR. Diverse lignocellulosic feedstocks can achieve high field-scale ethanol yields while providing flexibility for the biorefinery and landscape-level environmental benefits. GCB Bioenergy 2018;10(11):825-40. https://doi.org/10.1111/gcbb.12533.

[60] Tye YY, Lee KT, Abdullah WNW, Leh CP. The world availability of non-wood lignocellulosic biomass for the production of cellulosic ethanol and potential pretreatments for the enhancement of enzymatic saccharification. Renew Sustain Energy Rev 2016;60:155-72. https:// doi.org/10.1016/j.rser.2016.01.072.

[61] Kennes D, Abubackar HN, Diaz M, Veiga MC, Kennes C. Bioethanol production from biomass: carbohydrate vs syngas fermentation. J Chem Technol Biotechnol 2016;91(2): 304-17. https://doi.org/10.1002/jctb.4842.

[62] Hafid HS, Nor'Aini AR, Mokhtar MN, Talib AT, Baharuddin AS, Kalsom MSU. Over production of fermentable sugar for bioethanol production from carbohydrate-rich Malaysian food waste via sequential acidenzymatic hydrolysis pretreatment. Waste Manag 2017;67: 95-105. https://doi.org/10.1016/j.wasman.2017.05.017.

[63] Mussatto SI, Dragone G, Guimar aes PMR, Silva JPA Carneiro LM, Roberto IC, et al. Technological trends, global market, and challenges of bio-ethanol production. Biotechnol Adv 2010;28:817e30. https://doi.org/10.1016/ j.biotechadv.2010.07.001.

[64] Ellis JT, Miller CD. Fuel alcohols from microalgae. In: Algae biotechnology. Cham: Springer; 2016. p. 143-54. https:// doi.org/10.1007/978-3-319-12334-9_8.

[65] Singh R, Parihar P, Singh M, Bajguz A, Kumar J, Singh S, ..., Prasad SM. Uncovering potential applications of cyanobacteria and algal metabolites in biology, agriculture and medicine: current status and future prospects. Front Microbiol 2017;8:515. https://doi.org/10.3389/ fmicb.2017.00515.

[66] Kircher M. Sustainability of biofuels and renewable chemicals production from biomass. Curr Opin Chem Biol 2015; 29:26-31. https://doi.org/10.1016/j.cbpa.2015.07.010.

[67] Agarwal AK, Gupta JG, Dhar A. Potential and challenges for large-scale application of biodiesel in automotive sector. Prog Energy Combust Sci 2017;61:113-49. https://doi.org/ 10.1016/j.pecs.2017.03.002.

[68] Verma P, Sharma MP, Dwivedi G. Impact of alcohol on biodiesel production and properties. Renew Sustain Energy Rev 2016;56:319-33. https://doi.org/10.1016/ j.rser.2015.11.048.

[69] Mahmudul HM, Hagos FY, Mamat R, Adam AA, Ishak WFW, Alenezi R. Production, characterization and performance of biodiesel as an alternative fuel in diesel engines- A review. Renew Sustain Energy Rev 2017;72: 497-509. https://doi.org/10.1016/j.rser.2017.01.001.

[70] Sipra AT, Gao N, Sarwar H. Municipal solid waste (MSW) pyrolysis for bio-fuel production: a review of effects of MSW components and catalysts. Fuel Process Technol 2018; 175:131-47. https://doi.org/10.1016/j.fuproc.2018.02.012.

[71] Materazzi M, Holt A. Experimental analysis and preliminary assessment of an integrated thermochemical process for production of low-molecular weight biofuels from municipal solid waste (MSW). Renew Energy 2019;143: 663-78. https://doi.org/10.1016/j.renene.2019.05.027.

[72] Su Y, Zhang P, Su Y. An overview of biofuels policies and industrialization in the major biofuel producing countries. Renew Sustain Energy Rev 2018;50:991-1003. https:// doi.org/10.1016/j.rser.2015.04.032. 
[73] Costantini V, Crespi F, Martini C, Pennacchio L. Demandpull and technology-push public support for eco-innovation: the case of the biofuels sector. Res Pol 2015;44(3): 577-95. https://doi.org/10.1016/j.respol.2014.12.011.

[74] Niphadkar S, Bagade P, Ahmed S. Bioethanol production: insight into past, present and future perspectives. Biofuels 2018;9(2):229-38. 17597269.2017.1334338.

[75] Kumari D, Singh R. Pretreatment of lignocellulosic wastes for biofuel production: a critical review. Renew Sustain Energy Rev 2018;90:877-91. https://doi.org/10.1016/ j.rser.2018.03.111.

[76] MV Rodionova RS, Poudyal I, Tiwari RA, Voloshin SK, Zharmukhamedov HG, Nam BK, et al. Allakhverdiev, biofuel production: challenges and opportunities. Int $\mathrm{J}$ Hydrogen Energy 2017;42(12):8450-61. https://doi.org/ 10.1016/j.ijhydene.2016.11.125.

[77] Rastogi M, Shrivastava S. Recent advances in second generation bioethanol production: an insight to pretreatment, saccharification and fermentation processes. Renew Sustain Energy Rev 2017;80:330-40. https://doi.org/10.1016/ j.rser.2017.05.225.

[78] Alvira P, Tomás-Pejó E, Ballesteros M, Negro MJ. Pretreatment technologies for an efficient bioethanol production process based on enzymatic hydrolysis: a review. Bioresour Technol 2010;101(13):4851-61. https://doi.org/ 10.1016/j.biortech.2009.11.093.

[79] da Silva Martins LH, Rabelo SC, da Costa AC. Effects of the pretreatment method on high solids enzymatic hydrolysis and ethanol fermentation of the cellulosic fraction of sugarcane bagasse. Bioresour Technol 2015;191:312-21. https:// doi.org/10.1016/j.biortech.2015.05.024.

[80] Zhuang X, Wang W, Yu Q, Qi W, Wang Q, Tan X, ..., Yuan Z. Liquid hot water pretreatment of lignocellulosic biomass for bioethanol production accompanying with high valuable products. Bioresour Technol 2016;199:68-75. https://doi.org/10.1016/j.biortech.2015.08.051.

[81] Chen H, Fu X. Industrial technologies for bioethanol production from lignocellulosic biomass. Renew Sustain Energy Rev 2016;57:468-78. https://doi.org/10.1016/ j.rser.2015.12.069.

[82] An YX, Zong MH, Wu H, Li N. Pretreatment of lignocellulosic biomass with renewable cholinium ionic liquids: biomass fractionation, enzymatic digestion and ionic liquid reuse. Bioresour Technol 2015;192:165-71. https://doi.org/ 10.1016/j.biortech.2015.05.064.

[83] Wu K, Ying W, Shi Z, Yang H, Zheng Z, Zhang J, et al. Fenton reaction-oxidized bamboo lignin surface and structural modification to reduce nonproductive cellulase binding and improve enzyme digestion of cellulose. ACS Sustainable Chem Eng 2018;6(3):3853-61. https://doi.org/ 10.1021/acssuschemeng.7b04191.

[84] Tiwari R, Nain L, Labrou NE, Shukla P. Bioprospecting of functional cellulases from metagenome for second generation biofuel production: a review. Crit Rev Microbiol 2018; 44(2):244-57. 1040841X.2017.1337713.

[85] Wyman CE. Ethanol production from lignocellulosic biomass: overview. In: Handbook on bioethanol. Routledge; 2018. p. 1-18.

[86] Ballesteros LF, Michelin M, Vicente AA, Teixeira JA, Cerqueira MÂ. Lignocellulosic materials: sources and processing technologies. In: Lignocellulosic materials and their use in bio-based packaging. Cham: Springer; 2018. p. 13-33. https://doi.org/10.1007/978-3-319-92940-8_2.

[87] Achinas S, Euverink GJW. Consolidated briefing of biochemical ethanol production from lignocellulosic biomass. Electron J Biotechnol 2016;23:44-53. https:// doi.org/10.1016/j.ejbt.2016.07.006.

[88] Bugg TDH, Ahmad M, Hardiman EM, Rahmanpour R. Pathways for degradation of lignin in bacteria and fungi. Nat Prod Rep 2011;28:1883-96. https://doi.org/10.1039/ C1NP00042J.
[89] Gonzalez-Fernandez C, Sialve B, Bernet N, Steyer JP. Impact of microalgae characteristics on their conversion to biofuel. Part II: focus on biomethane production. Biofuels, Bioprod Bioref 2012;6:205-18. https://doi.org/10.1002/ bbb.337.

[90] Zabed HM, Akter S, Yun J, Zhang G, Awad FN, Qi X, et al. Recent advances in biological pretreatment of microalgae and lignocellulosic biomass for biofuel production. Renew Sustain Energy Rev 2019;105:105-28. https://doi.org/ 10.1016/j.rser.2019.01.048.

[91] Kumari D, Singh R. Pretreatment of lignocellulosic wastes for biofuel production: a critical review. Renew Sustain Energy Rev 2018;90:877-91. https://doi.org/10.1016/ j.rser.2018.03.111.

[92] Capolupo L, Faraco V. Green methods of lignocellulose pretreatment for biorefinery development. Appl Microbiol Biotechnol 2016;100(22):9451-67. https://doi.org/10.1007/ s00253-016-7884-y.

[93] Shen Z, Zhang K, Si M, Liu M, Zhuo S, Liu D. Synergy of lignocelluloses pretreatment by sodium carbonate and bacterium to enhance enzymatic hydrolysis of rice straw. Bioresour Technol 2018;249:154-60. https://doi.org/10.1016/ j.biortech.2017.10.008.

[94] Khoo KS, Chew KW, Yew GY, Leong WH, Chai YH, Show PL, et al. Recent advances in downstream processing of microalgae lipid recovery for biofuel production. Bioresour Technol 2020;304:122996. https://doi.org/10.1016/ j.biortech.2020.122996.

[95] Lu-Chau TA, García-Torreiro M, López-Abelairas $M$, Gómez-Vanegas NA, Gullón B, Lema JM, et al. Application of fungal pretreatment in the production of ethanol from crop residues. In: Bioethanol production from food crops. Academic Press; 2019. p. 267-92. https://doi.org/10.1016/ B978-0-12-813766-6.00014-X.

[96] Saratale RG, Kumar G, Banu R, Xia A, Periyasamy S, Saratale GD. A critical review on anaerobic digestion of microalgae and macroalgae and co-digestion of biomass for enhanced methane generation. Bioresour Technol 2018;262: 319-32. https://doi.org/10.1016/j.biortech.2018.03.030.

[97] Hernández D, Riaño B, Coca M, García-González MC Saccharification of carbohydrates in microalgal biomass by physical, chemical and enzymatic pre-treatments as a previous step for bioethanol production. Chem Eng J 2015;262: 939-45. https://doi.org/10.1016/j.cej.2014.10.049.

[98] Vasco-Correa J, Ge X, Li Y. Fungal pretreatment of nonsterile miscanthus for enhanced enzymatic hydrolysis. Bioresour Technol 2016;203:118-23. https://doi.org/10.1016/ j.biortech.2015.12.018.

[99] Barua VB, Goud VV, Kalamdhad AS. Microbial pretreatment of water hyacinth for enhanced hydrolysis followed by biogas production. Renew Energy 2018;126:21-9. https:// doi.org/10.1016/j.renene.2018.03.028.

[100] García-Torreiro M, López-Abelairas M, Lu-Chau TA Lema JM. Fungal pretreatment of agricultural residues for bioethanol production. Ind Crop Prod 2016;89:486-92. https://doi.org/10.1016/j.indcrop.2016.05.036.

[101] Sindhu R, Binod P, Pandey A. Biological pretreatment of lignocellulosic biomass-An overview. Bioresour Technol 2016;199:76-82. j.biortech.2015.08.030Get.

[102] Baruah J, Nath BK, Sharma R, Kumar S, Deka RC, Baruah DC, et al. Recent trends in the pretreatment of lignocellulosic biomass for value-added products. Front Energy Res 2018;6:141. https://doi.org/10.3389/ fenrg.2018.00141.

[103] Ko S, Lautala P, Handler RM. Securing the feedstock procurement for bioenergy products: a literature review on the biomass transportation and logistics. J Clean Prod 2018;200: 205-18. https://doi.org/10.1016/j.jclepro.2018.07.241.

[104] Lindkvist E, Karlsson M. Biogas production plants; existing classifications and proposed categories. J Clean Prod 2018; 174:1588-97. https://doi.org/10.1016/j.jclepro.2017.10.317. 
[105] Zamani A, Marjani AP, Mousavi Z. Agricultural waste biomass-assisted nanostructures: synthesis and application. Green Process Synth 2019;8(1):421-9.

[106] Wang Y, Fan C, Hu H, Li Y, Sun D, Wang Y, et al. Genetic modification of plant cell walls to enhance biomass yield and biofuel production in bioenergy crops. Biotechnol Adv 2016;34(5):997-1017. j.biotechadv.2016.06.001.

[107] Paschalidou A, Tsatiris M, Kitikidou K. Energy crops for biofuel production or for food?-SWOT analysis (case study: Greece). Renew Energy 2016;93:636-47. https://doi.org/ 10.1016/j.renene.2016.03.040.

[108] Coma M, Martinez-Hernandez E, Abeln F, Raikova S, Donnelly J, Arnot TC, et al. Organic waste as a sustainable feedstock for platform chemicals. Faraday Discuss 2017;202: 175-95. https://doi.org/10.1039/C7FD00070G.

[109] Heimann K. Novel approaches to microalgal and cyanobacterial cultivation for bioenergy and biofuel production. Curr Opin Biotechnol 2016;38:183-9. https://doi.org/ 10.1016/j.copbio.2016.02.024

[110] Kumar A, Kushal S, Saraf SA, Singh JS. Microbial biofuels: a solution to carbon emissions and energy crisis. Front BiosciLandmark 2018;23:1789-802.

[111] Yaşar F. Comparision of fuel properties of biodiesel fuels produced from different oils to determine the most suitable feedstock type. Fuel 2020;264:116817. https://doi.org/ 10.1016/j.fuel.2019.116817.

[112] Sander A, Košćak MA, Kosir D, Milosavljević N, Vuković JP, Magić L. The influence of animal fat type and purification conditions on biodiesel quality. Renew Energy 2018;118: 752-60. https://doi.org/10.1016/j.renene.2017.11.068.

[113] Liu W, Lu G, Yang G, Bi Y. Improving oxidative stability of biodiesel by cis-trans isomerization of carbon-carbon double bonds in unsaturated fatty acid methyl esters. Fuel 2019; 242:133-9. https://doi.org/10.1016/j.fuel.2018.12.132.

[114] Kumar SA, Sakthinathan G, Vignesh R, Banu JR, Ala'a H. Optimized transesterification reaction for efficient biodiesel production using Indian oil sardine fish as feedstock. Fuel 2019;253:921-9. https://doi.org/10.1016/j.fuel.2019.04.172.

[115] Lin CY, Fan CL. Fuel properties of biodiesel produced from Camellia oleifera Abel oil through supercritical-methanol transesterification. Fuel 2011;90:2240-4. https://doi.org/ 10.1016/j.fuel.2011.02.020.

[116] Ranjan A, Dawn SS, Jayaprabakar J, Nirmala N, Saikiran K, Sriram SS. Experimental investigation on effect of $\mathrm{MgO}$ nanoparticles on cold flow properties, performance, emission and combustion characteristics of waste cooking oil biodiesel. Fuel 2018;220:780-91. https://doi.org/10.1016/ j.fuel.2018.02.057.

[117] Abed KA, El Morsi AK, Sayed MM, El Shaib AA, Gad MS. Effect of waste cooking-oil biodiesel on performance and exhaust emissions of a diesel engine. Egypt J Petrol 2018; 27(4):985-9. https://doi.org/10.1016/j.ejpe.2018.02.008.

[118] Lin CY, Li RJ. Engine performance and emission characteristics of marine fish-oil biodiesel produced from the discarded parts of marine fish. Fuel Process Technol 2009; 90:883-8. https://doi.org/10.1016/j.fuproc.2009.04.009.

[119] Radhakrishnan S, Devarajan Y, Mahalingam A, Nagappan B. Emissions analysis on diesel engine fueled with palm oil biodiesel and pentanol blends. J Oil Palm Res 2017;29(3):380-6. https://doi.org/10.21894/jopr.2017.2903.11.

[120] Veljković VB, Biberdžić MO, Banković-Ilić IB, Djalović IG, Tasić MB, Nježić ZB, et al. Biodiesel production from corn oil: a review. Renew Sustain Energy Rev 2018;91:531-48. https://doi.org/10.1016/j.rser.2018.04.024.

[121] Hoekman SK, Broch A, Robbins C, Ceniceros E, Natarajan M. Review of biodiesel composition, properties, and specifications. Renew Sustain Energy Rev 2012;16(1): 143-69. https://doi.org/10.1016/j.rser.2011.07.143.

[122] Ge JC, Yoon SK, Choi NJ. Using canola oil biodiesel as an alternative fuel in diesel engines: a review. Appl Sci 2017; 7(9):881. https://doi.org/10.3390/app7090881.
[123] Raman LA, Deepanraj B, Rajakumar S, Sivasubramanian V. Experimental investigation on performance, combustion and emission analysis of a direct injection diesel engine fuelled with rapeseed oil biodiesel. Fuel 2019;246:69-74. https://doi.org/10.1016/j.fuel.2019.02.106.

[124] Elkelawy M, Bastawissi HAE, Esmaeil KK, Radwan AM, Panchal H, Sadasivuni KK, et al. Experimental studies on the biodiesel production parameters optimization of sunflower and soybean oil mixture and DI engine combustion, performance, and emission analysis fueled with diesel/ biodiesel blends. Fuel 2019;255:115791. https://doi.org/ 10.1016/j.fuel.2019.115791.

[125] de Freitas ON, Rial RC, Cavalheiro LF, dos Santos Barbosa JM, Nazário CED, Viana LH. Evaluation of the oxidative stability and cold filter plugging point of soybean methyl biodiesel/bovine tallow methyl biodiesel blends. Ind Crop Prod 2019;140:111667. https://doi.org/10.1016/ j.indcrop.2019.111667.

[126] Reyes JF, Sepulveda MA. PM-10 emissions and power of a diesel engine fueled with crude and refined biodiesel from salmon oil. Fuel 2006;85(12-13):1714-9. https://doi.org/ 10.1016/j.fuel.2006.02.001.

[127] Pereyra-Irujo GA, Izquierdo NG, Covi M, Nolasco SM, Quiroz F, Aguirrezábal LA. Variability in sunflower oil quality for biodiesel production: a simulation study. Biomass Bioenergy 2009;33(3):459-68. https://doi.org/ 10.1016/j.biombioe.2008.07.007.

[128] Mata TM, Mendes AM, Caetano NS, Martins AA. Properties and sustainability of biodiesel from animal fats and fish oil. Chem Eng Trans 2014;38:175-80.

[129] Lin CY, Wu SH. Comparison of lipid and biodiesel properties of Chaetoceros muelleri cultured in deep sea water and surface sea water. J Renew Sustain Energy 2017;9(1): 013104. https://doi.org/10.1063/1.4976555.

[130] Altendorf K, Isbell T, Wyse DL, Anderson JA. Significant variation for seed oil content, fatty acid profile, and seed weight in natural populations of field pennycress (Thlaspi arvense L.). Ind Crop Prod 2019;129:261-8. https://doi.org/ 10.1016/j.indcrop.2018.11.054.

[131] Grover A, Singh S, Singh A, Bala M. Jatropha: from seed to plant, seed, oil, and beyond. In: Jatropha, challenges for a new energy crop. Singapore: Springer; 2019. p. 323-46. https://doi.org/10.1007/978-981-13-3104-6_16.

[132] Patel VR, Dumancas GG, Viswanath LCK, Maples R, BJJ Subong. Castor oil: properties, uses, and optimization of processing parameters in commercial production. Lipid Insights 2016;9. https://doi.org/10.4137/LPI.S40233. LPIS40233.

[133] Islam AKMA, Primandari SRP, Yaakob Z. Non-edible vegetable oils as renewable resources for biodiesel production: south-East Asia perspective. Adv Biofuels Bioenergy 2018;201.

[134] Singh MK, Singh S, Ghoshal N. Impact of land use change on soil aggregate dynamics in the dry tropics. Restor Ecol 2017;25(6):962-71. https://doi.org/10.1111/rec.12523.

[135] Parawira W. Biodiesel production from Jatropha curcas: a review. Sci Res Essays 2010;5(14):1796-808. https://doi.org/ 10.1080/15567249.2016.1198846.

[136] Demirbas A, Kinsara RA. Cost analysis of biodiesel from kernel oil of tea seed. Energy Sources Part B Energy Econ Plann 2017;12(5):480-6. https://doi.org/10.1080/ 15567249.2016.1198846.

[137] Williams CL, Westover TL, Emerson RM, Tumuluru JS, $\mathrm{Li} \mathrm{C}$. Sources of biomass feedstock variability and the potential impact on biofuels production. BioEnergy Res 2016; 9(1):1-14. https://doi.org/10.1007/s12155-015-9694-y.

[138] de Jong S, Hoefnagels R, Wetterlund E, Pettersson K, Faaij A, Junginger $M$. Cost optimization of biofuel production-The impact of scale, integration, transport and supply chain configurations. Appl Energy 2017;195:1055-70. https://doi.org/10.1016/j.apenergy.2017.03.109.

[139] Bhuiya MMK, Rasul MG, Khan MMK, Ashwath N, Azad AK. Prospects of 2nd generation biodiesel as a 
sustainable fuel-part: 1 selection of feedstocks, oil extraction techniques and conversion technologies. Renew Sustain Energy Rev 2016;55:1109-28. https://doi.org/10.1016/ j.rser.2015.04.163.

[140] Callegari A, Bolognesi S, Cecconet D, Capodaglio AG. Production technologies, current role, and future prospects of biofuels feedstocks: a state-of-the-art review. Crit Rev Environ Sci Technol 2019:1-53. https://doi.org/10.1080/ 10643389.2019.1629801.

[141] Deshavath NN, Veeranki VD, Goud VV. Lignocellulosic feedstocks for the production of bioethanol: availability, structure, and composition. Sustain Bioenergy 2019:1-19. https://doi.org/10.1016/B978-0-12-817654-2.00001-0. Elsevier.

[142] Fenning TM, Walter C, Gartland KMA. Forest biotech and climate change. Nat Biotechnol 2008;26:615-7. https:// doi.org/10.1038/nbt0608-615.

[143] Toklu E. Biomass energy potential and utilization in Turkey. Renew Energy 2017;107:235-44. https://doi.org/10.1016/ j.renene.2017.02.008.

[144] Van der Stelt MJC, Gerhauser H, Kiel JHA, Ptasinski KJ. Biomass upgrading by torrefaction for the production of biofuels: a review. Biomass Bioenergy 2017;35(9):3748-62. https://doi.org/10.1016/j.biombioe.2011.06.023.

[145] Havukainen J, Nguyen MT, Väisänen S, Horttanainen M. Life cycle assessment of small-scale combined heat and power plant: environmental impacts of different forest biofuels and replacing district heat produced from natural gas. J Clean Prod 2018;172:837-46. https://doi.org/10.1016/ j.jclepro.2017.10.241.

[146] Meadowcroft J. Exploring negative territory Carbon dioxide removal and climate policy initiatives. Climatic Change 2013;118(1):137-49. https://doi.org/10.1007/s10584-012$0684-1$.

[147] Orr Jr FM. Carbon capture, utilization, and storage: an update. SPE J 2018;23(6):2-444.

[148] Dourado MN, Leite TF, Barroso PAV, Araújo WL. Genetically modified organisms in the tropics: challenges and perspectives. In: Diversity and benefits of micr oorganisms from the tropics. Cham: Springer; 2017. p. 403-30. https:// doi.org/10.1007/978-3-319-55804-2_18.

[149] Hurst WJ, Finley JW. Genetically modified crops. In: Principles of food chemistry. Cham: Springer; 2018. p. 511-26. https://doi.org/10.1007/978-3-319-63607-8 14.

[150] Ruggiero A, Punzo P, Landi S, Costa A, Van Oosten M, Grillo S. Improving plant water use efficiency through molecular genetics. Horticulturae 2017;3(2):31. https:// doi.org/10.3390/horticulturae3020031.

[151] Locke MA, Krutz LJ, Steinriede RW, Testa S. Conservation management improves runoff water quality: implications for environmental sustainability in a glyphosate-resistant cotton production system. Soil Sci Soc Am J 2015;79(2): 660-71. https://doi.org/10.2136/sssaj2014.09.0389.

[152] Chapotin S, Wolt J. Genetically modified crops for the bioeconomy: meeting public and regulatory expectations. Transgenic Res 2007;16:675-88. https://doi.org/10.1007/ s11248-007-9122-y.

[153] Huesing JE, Andres D, Braverman MP, Burns A, Felsot AS, Harrigan GG, et al. Global adoption of genetically modified (GM) crops: challenges for the public sector. J Agric Food Chem 2016;64(2):394-402. https://doi.org/10.1021/ acs.jafc.5b05116.

[154] Szabala BM, Osipowski P, Malepszy S. Transgenic crops: the present state and new ways of genetic modification. J Appl Genet 2014:1-8. https://doi.org/10.1007/s13353-0140210-4.

[155] McFadden BR, Lusk JL. What consumers don't know about genetically modified food, and how that affects beliefs? Faseb J 2016;30(9):3091-6. https://doi.org/10.1096/ fj.201600598.
[156] Bacenetti J, Bergante S, Facciotto G, Fiala M. Woody biofuel production from short rotation coppice in Italy: environmental-impact assessment of different species and crop management. Biomass Bioenergy 2016;94:209-19. https:// doi.org/10.1016/j.biombioe.2016.09.002.

[157] Lewandowski I. The role of perennial biomass crops in a growing bioeconomy. In: Perennial biomass Crops for a resource-constrained world. Cham: Springer; 2016. p. 3-13. https://doi.org/10.1007/978-3-319-44530-4_1.

[158] Bacenetti J, Bergante S, Facciotto G, Fiala M. Woody biofuel production from short rotation coppice in Italy: environmental-impact assessment of different species and crop management. Biomass Bioenergy 2016;94:209-19. https:// doi.org/10.1016/j.biombioe.2016.09.002.

[159] Boehmel C, Lewandowski I, Claupein W. Comparing annual and perennial energy cropping systems with different management intensities. Agric Syst 2008;96: 224-36. https://doi.org/10.1016/j.agsy.2007.08.004.

[160] Bansal A, Illukpitiya P, Tegegne F, Singh SP. Energy efficiency of ethanol production from cellulosic feedstock. Renew Sustain Energy Rev 2016;58:141-6. https://doi.org/ 10.1016/i.rser.2015.12.122.

[161] Perera PN, Schmidt M, Chiang VL, Schuck PJ, Adams PD. Raman-spectroscopy-based noninvasive microanalysis of native lignin structure. Anal Bioanal Chem 2012;402(2): 983-7. https://doi.org/10.1007/s00216-011-5518-x.

[162] Ge X, Xu F, Vasco-Correa J, Li Y. Giant reed: a competitive energy crop in comparison with miscanthus. Renew Sustain Energy Rev 2016;54:350-62. https://doi.org/10.1016/ j.rser.2015.10.010.

[163] Peng X, Li C, Liu J, Yi Z, Han Y. Changes in composition, cellulose degradability and biochemical methane potential of Miscanthus species during the growing season. Bioresour Technol 2017;235:389-95. https://doi.org/10.1016/ j.biortech.2017.03.128.

[164] Cui Z, Liu Y, Jia C, Huang Z, He H, Han F,, Wu GL. Soil water storage compensation potential of herbaceous energy crops in semi-arid region. Field Crop Res 2018;223:41-7. https://doi.org/10.1016/j.fcr.2018.03.026.

[165] Molino A, Chianese S, Musmarra D. Biomass gasification technology: the state of the art overview. J Energy Chem 2016;25(1):10-25. j.jechem.2015.11.005.

[166] Hassan SS, Williams GA, Jaiswal AK. Moving towards the second generation of lignocellulosic biorefineries in the EU: drivers, challenges, and opportunities. Renew Sustain Energy Rev 2019;101:590-9. https://doi.org/10.1016/ j.rser.2018.11.041.

[167] Paschalidou A, Tsatiris M, Kitikidou K. Energy crops for biofuel production or for food?-SWOT analysis (case study: Greece). Renew Energy 2016;93:636-47. https://doi.org/ 10.1016/j.renene.2016.03.040.

[168] Mitchell RB, Schmer MR, Anderson WF, Jin V, Balkcom KS, Kiniry J, et al. Dedicated energy crops and crop residues for bioenergy feedstocks in the central and eastern USA. BioEnergy Res 2016;9(2):384-98. https://doi.org/10.1007/ s12155-016-9734-2.

[169] Cui W, Cheng JJ. Growing duckweed for biofuel production: a review. Plant Biol 2015;17:16-23. https://doi.org/ $10.1111 / \mathrm{plb} .12216$.

[170] dos Santos IFS, Vieira NDB, de Nóbrega LGB, Barros RM, Tiago Filho GL. Assessment of potential biogas production from multiple organic wastes in Brazil: impact on energy generation, use, and emissions abatement. Resour Conserv Recycl 2018;131:54-63. https://doi.org/10.1016/ j.resconrec.2017.12.012.

[171] Gu M, Song W, Buhain J. Bioenergy and biofuels: history, status, and perspective. Renew Sustain Energy Rev 2015;42: 712-25. https://doi.org/10.1016/j.rser.2014.10.013. 
[172] Sheikh RA, Al-Bar OA, Soliman YMA. Biochemical studies on the production of biofuel (bioethanol) from potato peels wastes by Saccharomyces cerevisiae: effects of fermentation periods and nitrogen source concentration. Biotechnol Biotechnol Equip 2016;30(3):497-505. https://doi.org/ 10.1080/13102818.2016.1159527.

[173] Jalilian N, Najafpour GD, Khajouei M. Macro and micro algae in pollution control and biofuel production-a review. ChemBioEng Rev 2020;7(1):18-33. https://doi.org/10.1002/ cben.201900014.

[174] Alami AH, Alasad S, Ali M, Alshamsi M. Investigating algae for $\mathrm{CO} 2$ capture and accumulation and simultaneous production of biomass for biodiesel production. Sci Total Environ 2021;759:143529. https://doi.org/10.1016/ j.scitotenv.2020.143529.

[175] Alavijeh RS, Karimi K, Wijffels RH, van den Berg C, Eppink M. Combined bead milling and enzymatic hydrolysis for efficient fractionation of lipids, proteins, and carbohydrates of Chlorella vulgaris microalgae. Bioresour Technol 2020;309:123321. https://doi.org/10.1016/ j.biortech.2020.123321.

[176] Adeniyi OM, Azimov U, Burluka A. Algae biofuel: current status and future applications. Renew Sustain Energy Rev 2018;90:316-35. https://doi.org/10.1016/j.rser.2018.03.067. 